\title{
Cytokine Panel 12
}

National Cancer Institute

\section{Source}

National Cancer Institute. Cytokine Panel 12. NCI Thesaurus. Code C92627.

An assay to detect the presence and level of 12 cytokines in a blood sample (IFN gamma,

IL1 beta, IL10, IL12, IL13, IL2, IL2R, IL4, IL5, IL6, IL8, T NF alpha). 